\title{
Effect of Hormone Replacement Therapy (HRT) and low-dose combined oral pill on skin thickness, lipid profile and blood chemistry of menopausal women
}

Ali Baziad

\begin{abstract}
Abstrak
Penelitian ini untuk melihat efek terapi sulih hormon ("HRT") dan pil kombinasi dosis rendah terhadap ketebalan kulit ( kolagen ), profil lipid dan kimia darah pada wanita menopause. Penilitian ini berlangsung selama 1 tahun. Sebanyak 36 wanita menopause dilakukan randomisasi yaitu 18 orang mendapat HRT dan 18 orang mendapatkan pil kombinasi dosis rendah. Hasil penelitian ini menunjukkan bahwa terjadi peningkatan ketebalan kulit ( kolagen) baik pada wanita yang mendapat HRT maupun pada wanita yang mendapat pil kombinasi dosis rendah. Namun peningkatan ketebalan kulit lebih besar pada wanita yang menggunakan pil kombinasi dosis rendah. Peningkatan ketebalan kulit tersebut dapat mencegan osteoporosis. Pemberian HRT maupun pil kombinasi dosis rendah terjadi perubahan profil lipid maupun kimia darah, namun perubahan tersebut masih dalam batas normal. Pemberian pil kombinasi dosis rendah dapat dipertimbangkan diberikan pada wanita menopause. (Med J Indones 2003; 12: 224-8)
\end{abstract}

\begin{abstract}
This study to evaluate the effect of hormone replacement therapy ( HRT ) and low-dose combinated oral pill on skin thickness, lipid profile and blood chemistry on menopausal woman.This study was carried out in one year randomized prospective study. 36 women were divided into 18 women receiving HRT and the other 18 receiving low-dose oral pill. The result of this study showed an increase in skin thickness ( collagen) in both groups. But Those received low dose oral pill showed more. The increase of the skin thickness can prevent osteoporosis. The administration of HRT or low-dose oral pill could cause allteration in blood lipip profile and blood chemistry. But The changes were still within in normal limit. The administration of low-dose oral pill can be considered in postmenopausal women. (Med J Indones 2003; 12: 224-8)
\end{abstract}

Keywords: Hormone replacement therapy, low-dose oral pill, menopausal women, skin thickness, lipid profile, blood chemistry.

Hormone replacement therapy (HRT) is a therapy used for treatment and prevention in menopausal women. One of the health problems associated with estrogen hormone deficiency is the increased rate of incidence of osteoporosis. Nearly $40 \%$ of women towards 70 years of age experienced bone fractures associated with osteoporosis. ${ }^{1}$ It has been shown that the administration of HRT can reduce the incidence of osteoporosis up to $50 \% .^{2}$

In addition to preventing bone fractures, the administration of HRT has also been shown to reduce the risks of coronary diseases. HRT is a causal factor in

Department of Obstetrics and Gynecology, Faculty of Medicine, University of Indonesia/Dr. Cipto Mangunkusumo Hospital, Jakarta, Indonesia the increase of HDL and decrease of LDL. Furthermore, since HRT generally contains natural estrogen progestogen, it does not affect liver function in any significant way. However, since HRT is relatively expensive, it is not affordable by most women in Indonesia.

The use of contraceptive pills in menopausal women is still a subject of controversy. Contraceptive pills contain synthetic estrogen and progestogen. Synthetic estrogen and progestogen belong to the powerful types of sex steroid, as they may be used for preventing osteoporosis and other diseases associated with estrogen hormone deficiency. Nevertheless, since the costs of these agents are relatively low, their use in women of meno-pausal age requires great care. There is a great number of contraindications to the administration of oral contra-ceptives, such as hypertension, diabetes mellitus, liver dysfunction, stroke history, and severe varices. These diseases constitute con- 
traindications to the adminis-tration of oral pills; however, they are indications to the administration of HRT. ${ }^{3}$

Until recently diagnosis of osteoporosis commonly used was obtained through the use of radio isotope (Single Photon Absorptiometer), Dual Photon Absorptiometry (DPA), Dual Energy X Ray Absorptiometry (DXA) and CT Scan. Unfortunately, examinations by means of these technologies are expensive and carry the risk of radiation. Currently, a simpler, more inexpensive and risk-free examination equipment has been available for patients, i.e. trans-dermal USG. This equipment is used to measure skin thickness of a woman. By measuring skin thickness (collagen), it can be identified whether a bone has undergone osteoporosis or not. If collagen content in the skin decreases, it can be concluded that collagen content in the bone has also decreased.

\section{METHODS}

This study was designed as a one-year, randomized, prospective, and open-label study. Participants of the study were randomly allocated to either HRT or lowdose combined oral pills. Doses of HRT were 17 beta estradiol $2 \mathrm{mg}+$ medroxyprogesteron acetate $2.5 \mathrm{mg}$ administered continuously. Doses of combined oral pills were $20 \mu \mathrm{g}$ of etinyl estradiol $+150 \mu \mathrm{g}$ of desogestrel. This study aimed to evaluate the administration of HRT and low-dose pills before and after one year in menopausal women in terms of FSH hormones, lipid profile, blood chemistry, and skin thickness. Subjects of the study had education level at least for 12 years, were cooperative and were be willing to sign an informed consent. Criteria of exclusion applied subjects with known or suspected hormonal dependence tumor, cerebrovascular disease or history of cerebrovascular and cardiovascular disease, such as thrombophlebitis and thrombo-embolic process, vaginal bleeding with unexplained cause, severe liver and renal disease, have received estrogen therapy and/or drugs known to have effects in treating climacteric complaints for the last three months, haemolytic anemia and sickle cell, blood pressure above 160/95 $\mathrm{mm} \mathrm{Hg}$, latent diabetes mellitus. All patients still had intact uterus and ovaries. General condition and gynecological status were examined including blood pressure, body weight, height, sclera, conjunctiva, lymphaticgland, heart, lungs, abdomen, vulva, vagina, and internal genitalia. Examination of cervical cytology (pap smear) and mammography were performed.
The study was performed at a private menopausal clinic Menox and Androx in Jakarta, from January 2002 to January 2003. Measurement of skin thickness was done by means of transdermal ultrasound "Osteoson" made in Germany with high resolution (20 Mhz). Area of skin measured was the upper inside left arm.

\section{RESULTS}

Table 1. Mean values of variables

\begin{tabular}{lrrcc}
\hline Characteristics & HRT & SEM & $\begin{array}{c}\text { Combined } \\
\text { oral }\end{array}$ & $\begin{array}{c}\text { SEM } \\
\text { pill }\end{array}$ \\
\hline Menopausal age (year) & 53 & \pm 1.02 & 54.4 & \pm 1.51 \\
Menopausal length (year) & 3.67 & \pm 0.60 & \pm 5.4 & \pm 1.10 \\
\hline
\end{tabular}

Table 2. Effects of HRT on FSH and skin thickness

\begin{tabular}{lrrrrrr}
\hline & $\begin{array}{c}\text { Before } \\
\text { treatment }\end{array}$ & SEM & $\begin{array}{c}\text { After } \\
\text { treatment }\end{array}$ & SEM & $p$ \\
\hline FSH ( mIU/ml) & 87.88 & \pm 22.46 & 19.28 & \pm 2.10 & $<0.05$ \\
Skin thickness (mm) & 0.95 & \pm 0.14 & 0.98 & \pm 0.12 & 0.74 \\
\hline
\end{tabular}

Table 3. Effects of combined oral pill on FSH and skin thickness

\begin{tabular}{lrcccc}
\hline & Before & SEM & After & SEM & $p$ \\
\hline FSH (mIU/ml) & 67.52 & \pm 7.71 & 7.62 & \pm 1.13 & $<0,001$ \\
Skin thickness & 0.92 & \pm 0.16 & 0.99 & \pm 0.18 & $<0.005$ \\
\hline
\end{tabular}

Table 4. Effects of HRT on blood chemistry

\begin{tabular}{lccccc}
\hline Blood chemistry & Before & SEM & After & SEM & $p$ \\
\hline SGOT $(\mathrm{u} / \mathrm{I})$ & 18.28 & 2.91 & \pm 21.94 & \pm 3.97 & 0.35 \\
SGPT $(\mathrm{u} / \mathrm{I})$ & 16.67 & 1.34 & \pm 18.39 & \pm 1.71 & 0.53 \\
\hline
\end{tabular}

Table 5. Effects of HRT on lipid profile

\begin{tabular}{lccccc}
\hline Lipid profile & Before & SEM & After & SEM & $p$ \\
\hline LDL (mg/dl) & 144.11 & \pm 7.45 & 140.44 & \pm 6.88 & 0.06 \\
HDL (mg/dl) & 61.44 & \pm 2.17 & 63.06 & \pm 2.43 & 0.21 \\
Total cholesterol (mg/dl) & 221.83 & \pm 7.12 & 211.00 & \pm 9.09 & 0.15 \\
Trigylceride (mg/dl) & 98 & 6.23 & 85 & 5.61 & 0.40
\end{tabular}


Table 6. Effects of combined oral pill on blood chemistry

\begin{tabular}{lccccc}
\hline Blood chemistry & Before & SEM & After & SEM & $p$ \\
\hline SGOT $(u / I)$ & 17.50 & \pm 1.06 & 19.89 & \pm 1.32 & $<0.01$ \\
SGPT $(u / I)$ & 17.72 & \pm 1.82 & 18.39 & \pm 1.72 & 0.36 \\
\hline
\end{tabular}

Table 7. Effects of combined oral pill on lipid profile

\begin{tabular}{lccccc}
\hline Lipid profile & $\begin{array}{c}\text { Before } \\
\text { treatment }\end{array}$ & SEM & $\begin{array}{c}\text { After } \\
\text { treatment }\end{array}$ & SEM & $p$ \\
\hline LDL (mg/dl) & 14.89 & \pm 6.24 & 129.83 & \pm 5.23 & 0.10 \\
$\begin{array}{l}\text { HDL (mg/dl) } \\
\text { Total cholesterol } \\
(\mathrm{mg} / \mathrm{dl})\end{array}$ & 49.67 & \pm 3.57 & 55.22 & \pm 4.52 & $<0.05$ \\
$\begin{array}{c}\text { Trigylceride } \\
(\mathrm{mg} / \mathrm{dl})\end{array}$ & 223 & \pm 6.59 & 207 & \pm 5.30 & 0.11 \\
\hline
\end{tabular}

\section{DISCUSSION}

In this study, mean age of menopause was 53 years, and length of menopause 3.6 years (Table 1). This means that all patients were postmenopausal. In women of postmenopausal age, it is advisable to administer HRT continuously. This method of administration will not result in withdrawal bleeding; however, continuous combined administration increases the incidence of spotting.,

Examination of FSH hormones was performed to determine whether a patient has entered menopausal age or not. Tables 2 and 3 show high levels of FSH, indicating that both ovaries have not functioned any longer in producing estrogen. The administration of either HRT or combine oral pills resulted in the significantly decreased level of FSH. Because combined oral pills contained synthetic estrogen and progestogen, the suppression of FSH became more effective than the suppression by HRT containing natural estrogen and progestogen.

Tables 2 and 3 show that mean skin thickness in the group of HRT before therapy was $0.95 \pm \mathrm{SD} \mathrm{mm}$, while in the group receiving combined oral pills before therapy was $0.92 \pm \mathrm{SD} \mathrm{mm}$, sugesting that the collagen levels of all patients have decreased. Normal value of skin thickness was $>1.00 \mathrm{~mm} .{ }^{6}$ In 1987 , Brincart $^{6}$ found a decrease in the collagen level of the skin and bone which occurring proportionately to the increase of age. As a result of estrogen deficiency, the skin' thickness decreases gradually. ${ }^{7}$ In this study, the decrease in the skin's collagen level showed that the patient suffered from osteoporosis. When the skin's collagen level decreases, the bone's collagen level will decreases correspondingly.

After one year of HRT administration, an increase in skin thickness was observed, i.e. from $0.95 \mathrm{~mm}$ to $0.98 \mathrm{~mm}$. On the other hand, in patients receiving combined oral pills a significant increase in the skin thickness was found. Posibly the increase of skin thickness considerably depended on the type of progestogen used. The study performed by Baziad ${ }^{8}$ in 1994 found no significant increase in skin thickness in postmenopausal women receiving natural estrogen and progestogen for a period of one year. Several investigators have demonstrated that noretisteronederivative progestogen, such as found in combined oral pills, when combined with natural estrogen as HRT, increased skin collagen by $50 \% .{ }^{69}$ In 2001 , Baziad reported a significant increase in skin thickness of postmenopausal women receiving HRT for six months. This HRT contained natural estrogen and noretisteron-derivative progestogen (norestosterone acetate). ${ }^{10}$

In the present study, an increase in SGOT and SGPT levels was noted with the administration of HRT; however, this increase was not significant. The increase occurring was still within normal values (normal value of SGOT was 11-36 u/l, SGPT 10-65 u/l). As a matter of fact, there was a slight increase in SGOT in menopausal women, and estrogen administration did not significantly affect SGOT level ${ }^{(11,12)}$. Because there was an increase in both SGOT and SGPT after the administration of HRT, HRT should be administered with great care in postmenopausal women with liver dysfunction. ${ }^{13,14}$ Transdler application is preferable in the administration of combined oral pills there was an increase in SGOT level. In addition, the administration of combined oral pills resulted in significant increase of SGPT level. The increase in SGPT level occurred because testosteronderivative synthetic progestogen present in the pills needed to be first activated in the liver into its active form. This activation process put enormous burden on liver function, and this is the primary reason why contraceptive pills are not generally recommended to be used as HRT. However, when it should be used as HRT, a regular observation of liver functions is necessary. 
From various studies it was evident that high level of HDL has protective effect on the heart, ${ }^{14,15}$ while high level of LDL increases the risk of coronary heart disease. ${ }^{14}$ In the present study, a slight increase in LDL level after one-year administration of HRT was observed. Progesterone derivat progestogen, such as medroxyprogesteron acetate, very slightly affects lipid metabolism. ${ }^{16}$ In this study, the type of progestogen used was medroxyprogesteron acetate (MPA). After one-year administration of HRT, a decrease in LDL serum level was found, i.e. from $141.89 \mathrm{mg} / \mathrm{dl}$ to $140.44 \mathrm{mg} / \mathrm{dl}$. This decrease was still within normal values (normal values: $60-160 \mathrm{mg} / \mathrm{dl}$ ). The administration of combined oral pills resulted in the decrease of LDL level from $144.11 \mathrm{mg} / \mathrm{dl}$ to $129.83 \mathrm{mg} / \mathrm{dl}$, and significant increase of HDL serum was observed. Synthetic estrogen, such as etinilestradiol commonly contained in combined contraceptive pills, was indisputably very effective in increasing HDL level, thus making it very beneficial in preventing coronary heart disease. It should be noted, however, that ethinilestradiol has the ability to increase angiotensinogen level several times, and increase blood coagulation factor leading to the increased blood pressure and increase the risk of thrombosis. ${ }^{17,18}$ Therefore, combined contraceptive pills should not be administered in menopausal women with high blood pressure and varices. Since it contains natural estrogen, HRT is not a contraindication to menopausal women with either hypertension or varices.

It has been shown from epidemiological studies that decrease in total cholesterol level by 2-3\% may reduce the risk of coronary heart disease by $1 \% .{ }^{19}$ The administration of estrogen with or without a combination with progestogen may reduce total cholesterol level up to $10-20 \% .^{20,21}$ During postmenopausal period, total cholesterol level and trigylceride level generally increase, and with the administration of HRT these levels experience slight reduction. ${ }^{1}$ In this study, after one-year administration total cholesterol level decreased from $221.83 \mathrm{mg} / \mathrm{dl}$ to $211 \mathrm{mg} / \mathrm{dl}$, and triglyceride level decreased from $98 \mathrm{mg} / \mathrm{dl}$ to $85 \mathrm{mg} / \mathrm{dl}$, although statistically these decreases were not significant (normal values of total cholesterol were 150-225 $\mathrm{mg} / \mathrm{dl}$, triglyceride $40-145 \mathrm{mg} / \mathrm{dl})$. A decrease in total cholesterol level and a significant decrease in triglyceride level were also observed after the administration of combined oral pills. By contrast, the administration of only ethinilestradiol (50 ug) resulted in the increase of triglyceride level; however, when ethinilestradiol was combined with nortestosteron-derivative progestogen a decrease in triglyceride level was observed. ${ }^{1}$

\section{CONCLUSIONS}

The administration of combined oral pills containing synthetic estrogen and progestogen was able to increase skin thickness (collagen) significantly compared with the administration of HRT containing natural estrogen and progestogen. The administration of either HRT or combined oral pills resulted in the changes of lipid profile. An increase in SGOT and SGPT levels was observed after the administration of HRT and combined oral pills; however, this increase was still within normal limits.

\section{REFERENCES}

1. Kuhl H, Taubert HD. Postmenopausal Osteoporosis. In: Das Klimakterium. Georg Thime Verlag. Stuttgart-New York, 1987:291-322.

2. Conference Report Consensus Development Conference: prophylaxis and treatment of osteoporosis. $\mathrm{Br}$ Med J 1987;295:914-16.

3. Kenemans P, Barentsen R, van de Weijer P. Practical HRT. Medicom 1995: 149-153.

4. Mattson LA, Cullberg G, Samsioe G. Evaluation of continuous oestrogen-progestogen regimen for climacteric complaints. Maturitas 1982;4: 95-102.

5. Staland B. Continuous treatment with natural oestrogen and progestogens. A method to avoid endometrial stimulation. Maturitas 1981;3: 145-56.

6. Brincat M, Wong TYA. Response of skin thicknes and metacarpal to estradiol therapy in postmenopausal women. Obstet Gynec 1987;70:538.

7. Brincat M, Moniz CJ, Stud WW, Darby A, Mayor G, Embury $\mathrm{G}$ et al. Long-term effects of the menopause and sex hormones on skin thicknes. Br J Obstet Gynaecol 1985;92:256-59.

8. Baziad A, Salim A, Hedstiantoro A, kuhl H. Pengukuran ketebalan kulit untuk deteksi dini osteoporosis dengan USG transdermal pada wanita menopause yang mendapat terapi substitusi (measurement of skin thikness of detection osteoporosis with transdermal USG on menopause women receiving HRT). Indon J Obstet Gynecol, 1997;21:109-13.

9. Punnonen R, Vilska S, Rauramo L,. Skinfold thicknes and long -term postmenopausal hormone therapy. Maturitas 1984;5: 259-62.

10. Baziad A. Effects of continuous hormone replacement therapy on FSH, lipid profiles, blood chemistry, and skin thicknes in menopause women. Med J Indones 2002;17 : 97-103.

11. McPherson K, Healy MJR, Flynn FV, Piper KAJ, GarciaWeeb P. The effects of age, sex and other factors on blood chemistry in health. Clin. Chim. Acta 1978;84:373-97.

12. Wilding P, Rollason JG, Robinson D. Patterns of change for various biochemical constituents detected in well population screening. Clin Chim Acta 1972;41:375-87.

13. Moore B, Paterson MEL, Sturdee DW, Whitehead TP. The effect of menopausal status and sequential mestranol 
and noretisterone on serum biochemical profiles. $\mathrm{Br} \mathrm{J} \mathrm{Ob-}$ stet Gynaec 1981;88:853-8.

14. Levy RL, Cholesterol, lipoproteins, apoproteins, and heart disease : present status and future prospects. Clin Chem 1981;27:653-61.

15. Fisch FH, Huber JC. Die Hormonsubstitution in Wandel der Zeit. Krause \& Pachernegg GmbH, Gablitz 2000:11927.

16. Pickar JH, Wild RA, Walsh B, Hirvonen E, Lobo RA. Effects of different hormone replacement regimens on postmenopausal women with abnormal lipid levels. Climacteric 1998;1: 26-31.

17. Mandel FP, Geola FL, Meldrum DR, Lu JKH, Eggena P, Sambhi MP et al. Biologic effects of various doses of ethinyl estradiol in postmenopausal women. Obstet Gynec 1982;59:673-79.

18. Geola FL, Frumar AM, Tataryn IV, Lu KH, Hirshman $\mathrm{JM}$, Eggena $\mathrm{P}$ et al. Biological effects of various doses of conjugated equine estrogen in postmenopausal women. J Clin Endocr Obstet 1982;51: 620-25.

19. Kuhl H. Klimakterium, Postmenopause und Hormonsubstitution. Unimed Verlag, Bremen 1999: 95-101.

20. Kuhl H. Metabolische Effekte der Ostrogene und Gestagene. Gynekologe 1997;30: 357-69.

21. Kuhl H. Cardiovascular disease and estrogen replacement therapy-epidemiological data. In: lippert TH, Muck AO (eds). Sex Steroids and the Cardiovascular System. Pathernon London 1998: 97-109. 